\title{
Physico-Chemical Properties of Bottle Gourd Pulp (Lagenaria siceraria) Ujani basundi
}

\author{
S.B. Gawande, V.G. Atkare and S.B. Bhalerao* \\ Animal Husbandry and Dairy Science, College of Agriculture, Nagpur, India \\ *Corresponding author
}

Ke y w or d s
Ujanibasundi,
Bottle gourd,
Physico-chemical
parameters

\section{Introduction}

Basundi is defined as a preparation of boiled and sugared milk (cow or buffalo), used mostly in western parts and southern part of India. The Indian Dairy Federation defined the product as a confectionary based on concentrated milk.

Basundi as appearance like condensed milk with flakes that is thin flakes in thick fluid. It has a light brown color, smooth consistency with presence of very minute suspended flakes resembling that of plain condensed milk that having pleasant, cooked, nutty flavor. Basundi is an important indigenous desiccated whole milk product prepared by partial dehydration of the milk with sugar. The dehydration of milk is done in a karahi on direct fire. The original volume of milk is reduced to about of 40 to 50 per cent.

Ujani basundi is heat desiccated indigenous dairy product of Ujani village and popular 
throughout the Latur district in Maharashtra State. Special thing regarding this families and other manufacturing agent is that they do not prepare any dairy product except UjaniBasundi. Ujani village is situated on the SolapurLatur highway just near the famous religious place, Tuljapur. This product is very much popular in Ujani and around villages as well as all over the Latur District and border areas of Maharashtra and Karnataka (Gaikwad et al., 2009).

Bottle gourd (Lagenaria siceraria) belongs to Family Cucurbitaceae is commonly cultivated vegetable plant in tropical and subtropical areas of the world originated from southern Africa. Bottle gourd (Lagenaria siceraria) is one of the excellent fruit gifted by nature to human being having a well-balanced composition of all essential constituent that are required for good health and quality human life. It is rich in calcium, potassium other minerals and also contains vitamins, lipids and some amino acids also reported that bottle gourd (its fruit, juice, seed, powder) possess anti-hyperlipidemic, analgesic, antiinflammatory, diuretic, anti- oxidant, immunomodulatory, cardio-protective, anthelmistic and hepato-protective properties (Parle and Kaur, 2011).

Keeping these in mind, the present paper focused to study on physico-chemical properties of bottle gourd pulp (Lagenaria siceraria) UjaniBasundi”.

\section{Materials and Methods}

During the entire study fresh, clean, whole cow milk was obtained from Animal Husbandry and Dairy Science Section, College of Agriculture, Nagpur. The milk was strained through clean muslin cloth and transfer into well cleaned and sterilize flat bottom stainless steel vessel. The milk sample was analyzed for different milk constituent viz., fat, total solids, protein, solids not fat, acidity and ash etc. Cow milk was used for conducting the trial throughout the experiment. The milk was standardized at 4 per cent fat by using Pearson's square formula by the addition of skim milk as followed for adjustment of 4 per cent fat.

Good quality, fresh bottle gourd fruit was purchased from local market of Nagpur. The fruit was washed with clean fresh potable water. The skin was removed and fruit was cut into pieces with the help of knife and seed was removed. The pulp of fruit was made by using mixer cum grinder under hygienic condition was used in Ujanibasundi.

\section{Treatment details}

$\mathrm{T}_{1}=100$ Parts of cow milk +0 parts of bottle gourd pulp

$\mathrm{T}_{2}=95.0$ Parts of cow milk +5.0 parts of bottle gourd pulp

$\mathrm{T}_{3}=90.0$ Parts of cow milk +10 parts of bottle gourd pulp

$\mathrm{T}_{4}=85.0$ Parts of cow milk +15.0 parts of bottle gourd pulp

Note: 5 per cent sugars were common in all treatments.

\section{Analysed of bottle gourd pulp Ujanibasundi}

For determination of Fat, total solids, protein, SNF, ash and acidity content

Fat content of bottle gourd Ujani basundi was determined as per Gerber's method described in IS 1224 (Part-I) 1977.The percentage of total solids in bottle gourd Ujani basundi was determined by using gravimetric method as per the procedure of IS: 1479 (Part II) (1961). The protein content in basundi was determined as per the procedure recommended in IS: 1479 (Part II), 1961. SNF was determined by 
subtracting the percentage of fat from the percentage of total solids. The Ash content in basundi was determined as per the method recommended in IS: 1479 (part II) 1961 and acidity as per the method. It was determined as per the method described in BIS (1981).

\section{Statistical analysis}

The experiment was laid out in CRD with four treatment and five replications. The data obtained were analyzed statistically according to method described by Snedecor and Cochran (1994)

\section{Results and Discussion}

The finished product of bottle gourd Ujani basundi were subjected for the proximate analysis viz., fat, total solids, protein, solids not fat, ash and acidity. The results obtained on account of this parameter are presented in table 1 .

\section{Fat content}

The fat content in the finished product formulated under the different treatment combinations was estimated. The mean fat content in Ujani basundi samples was significantly affected due to the addition of bottle gourd pulp at different levels. The fat content in the Ujani basundi prepared with addition of bottle gourd pulp at 0 per cent $\left(\mathrm{T}_{1}\right)$, 5 per cent $\left(\mathrm{T}_{2}\right), 10$ per cent $\left(\mathrm{T}_{3}\right)$ and 15 per cent $\left(\mathrm{T}_{4}\right)$ were recorded as $18.50,17.30,16.70$ and 15.90 per cent, respectively. The results indicated that, with the increased in the levels of bottle gourd pulp there was significant reduction in fat percentage of Ujanibasundi. This might be due to the fact that fat content of bottle gourd was considerably less as compared to the fat content of milk. On contrary, Gaikwad et al., (2011) reported that the fat content in basundi was ranged from 17.66 to 18.62 per cent.

\section{Total solids content}

The average total solids content in Ujani basundi samples was significantly affected due to the addition of bottle gourd pulp at different levels. The total solids content in the Ujani basundi prepared with addition of bottle gourd pulp at 0 per cent $\left(T_{1}\right), 5$ per cent $\left(T_{2}\right)$, 10 per cent $\left(\mathrm{T}_{3}\right)$ and 15 per cent $\left(\mathrm{T}_{4}\right)$ were recorded as $44.87,46.45,47.88$ and 50.78 per cent, respectively. The total solids percentage was significantly highest (50.78 per cent) in Ujani basundi prepared with addition of 15 per cent of bottle gourd pulp $\left(\mathrm{T}_{4}\right)$ while, total solids content was lowest (44.87 per cent) in Ujani basundi prepared with addition of 0 per cent of bottle gourd pulp $\left(\mathrm{T}_{1}\right)$. It was found that, with the increased in the levels of bottle gourd pulp there was significantly increased in total solids percentage in Ujanibasundi. This might be due to the fact that total solids content of bottle gourd pulp was considerably more.

The present findings are in agreement with the results obtained by Raut (2018) recorded total solids content in basundi prepared with red pumpkin pulp ranged from $50.58 \pm 0.08$ to $53.30 \pm 0.27$ per cent under the treatment $\mathrm{T}_{0}(0 \%), \mathrm{T}_{1}(2.5 \%), \mathrm{T}_{2}(5 \%)$ and $\mathrm{T}_{3}(7.5 \%)$. It was observed that the significant increase in total solids content of basundi with red pumpkin pulp. Dubal (2009) also reported that mean total solids percentage of basundi $\mathrm{T}_{1}$ (5\%), $\mathrm{T}_{2}(10 \%), \mathrm{T}_{3}(15 \%)$ and $\mathrm{T}_{4}(20 \%)$ levels of mango pulp ranged from 42.91 to 47.65 per cent.

\section{Protein content}

The mean protein content in Ujani basundi samples was significantly affected due to the addition of bottle gourd pulp at different levels. The protein content in the Ujani basundi prepared with addition bottle gourd pulp at 0 per cent $\left(T_{1}\right), 5$ per cent $\left(T_{2}\right), 10$ per cent $\left(T_{3}\right)$ and 15 per cent $\left(T_{4}\right)$ were recorded 
as 10.20, 9.70, 9.20 and 8.70 per cent, respectively. Protein content was highest (10.20 per cent) in Ujani basundi prepared with addition of 0 per cent of bottle gourd pulp $\left(\mathrm{T}_{1}\right)$ while, protein percentage was significantly lowest (8.70 per cent) in Ujani basundi prepared with addition of 15 per cent of bottle gourd pulp $\left(\mathrm{T}_{4}\right)$. It is inferred that with the increased in the levels of bottle gourd pulp there was significantly decreased in protein percentage of Ujanibasundi. This might be due to the fact that protein content of bottle gourd pulp was considerably less $(0.2$ per cent) as compared to the protein content of milk.

More or less similar results were reported by Gaikwad et al., (2011) noticed that, protein content in basundi ranged from 10.25 to 11.25 with different levels of sugar $6 \%, 8 \%$ and 10 $\%$. The sample prepared with $10 \%$ sagar level showed lowest (10.25) percentage protein as compared to $6 \%$ (11.25) and $8 \%$ (10.75) of sugar level. Hence, protein content decreased in all treatments as sugar content increased.

Table.1 Physico-chemical attributes of Ujani basundi as affected by different levels of bottle gourd pulp (per cent)

\begin{tabular}{|c|c|c|c|c|c|c|}
\hline Treatments & Fat & Total solids & Protein & SNF & Acidity & Ash \\
\hline $\mathbf{T}_{\mathbf{1}}$ & $\mathbf{1 8 . 5 0}^{\mathbf{a}}$ & $\mathbf{4 4 . 8 7}^{\mathbf{d}}$ & $\mathbf{1 0 . 2 0}^{\mathbf{a}}$ & $\mathbf{2 0 . 7 0}^{\mathbf{a}}$ & $\mathbf{0 . 4 6}^{\mathbf{a}}$ & $\mathbf{2 . 0 0}^{\mathbf{a}}$ \\
$\mathbf{T}_{\mathbf{2}}$ & $\mathbf{1 7 . 3 0}^{\mathbf{b}}$ & $\mathbf{4 6 . 4 5}^{\mathbf{c}}$ & $\mathbf{9 . 7 0}^{\mathbf{b}}$ & $\mathbf{2 0 . 3 0}^{\mathbf{b}}$ & $\mathbf{0 . 4 2}^{\mathbf{b}}$ & $\mathbf{1 . 9 0}^{\mathbf{b}}$ \\
$\mathbf{T}_{\mathbf{3}}$ & $\mathbf{1 6 . 7 0}^{\mathbf{c}}$ & $\mathbf{4 7 . 8 8}^{\mathbf{b}}$ & $\mathbf{9 . 2 0}^{\mathbf{c}}$ & $\mathbf{2 0 . 0 0}^{\mathbf{c}}$ & $\mathbf{0 . 4 0}^{\mathbf{c}}$ & $\mathbf{1 . 8 0}^{\mathbf{c}}$ \\
$\mathbf{T}_{\mathbf{4}}$ & $\mathbf{1 5 . 7 0}^{\mathbf{d}}$ & $\mathbf{5 0 . 7 8}^{\mathbf{a}}$ & $\mathbf{8 . 7 0}^{\mathbf{d}}$ & $\mathbf{1 9 . 9 0}^{\mathbf{d}}$ & $\mathbf{0 . 3 9}^{\mathbf{d}}$ & $\mathbf{1 . 7 0}^{\mathbf{d}}$ \\
S.E. \pm & $\mathbf{0 . 0 4}$ & $\mathbf{0 . 2 8}$ & $\mathbf{0 . 0 3}$ & $\mathbf{0 . 1 4}$ & $\mathbf{0 . 0 0 6}$ & $\mathbf{0 . 0 1}$ \\
C.D & $\mathbf{0 . 1 4}$ & $\mathbf{0 . 8 5}$ & $\mathbf{0 . 1 0}$ & $\mathbf{0 . 4 3}$ & $\mathbf{0 . 0 1 8}$ & $\mathbf{0 . 0 4}$ \\
Result & Sig. & Sig. & Sig. & Sig. & Sig. & Sig. \\
\hline
\end{tabular}

\section{Ash content}

The mean ash content in Ujani basundi samples was significantly affected due to the addition of bottle gourd pulp at different levels. The ash content in the Ujani basundi prepared with addition of bottle gourd pulp at 0 per cent $\left(T_{1}\right), 5$ per cent $\left(T_{2}\right), 10$ per cent $\left(\mathrm{T}_{3}\right)$ and 15 per cent $\left(\mathrm{T}_{4}\right)$ were recorded as $2.00,1.90,1.80$ and 1.70 per cent, respectively. The ash content was significantly highest (2.00 per cent) in Ujani basundi prepared with addition of 15 per cent bottle gourd pulp $\left(\mathrm{T}_{4}\right)$ while, ash content was lowest (1.70 per cent) in Ujani basundi prepared with addition of 0 per cent bottle gourd pulp $\left(\mathrm{T}_{1}\right)$.The results indicated that with the increased in the levels of bottle gourd pulp there was significantly decreased in ash percentage of Ujanibasundi. This might be due to the fact that ash content of bottle gourd pulp was considerably less as compared to the ash content of milk.

More or less similar results were reported by Bhutkar et al., (2015), they prepared basundi with different combination of cow milk and bottle gourd pulp as 100:00 (T1), 95:05 (T2), 90:10 (T3) and 85:15 (T4).

They recorded $2.03,1.95,1.87$ and 1.79 per cent ash, respectively. These findings are well comparable with the results of present study.

\section{Solids not fat content}

The mean solids not fat content in Ujani basundi samples was significantly $(\mathrm{P}<0.05)$ affected due to the addition of bottle gourd pulp at different levels. Solids not fat contents 
in the Ujani basundi prepared with addition of bottle gourd pulp at 0 per cent $\left(\mathrm{T}_{1}\right), 5$ per cent $\left(\mathrm{T}_{2}\right), 10$ per cent $\left(\mathrm{T}_{3}\right)$ and 15 per cent $\left(\mathrm{T}_{4}\right)$ were 20.70, 20.30, 20.00 and 19.90 per cent, respectively.

The SNF per cent was significantly highest (20.70 per cent) in Ujani basundi prepared with addition of 0 per cent bottle gourd pulp $\left(\mathrm{T}_{1}\right)$ while, SNF content was lowest (19.90 per cent) in Ujani basundi prepared with addition of 15 per cent bottle gourd pulp $\left(\mathrm{T}_{4}\right)$.

The results indicated that, with the increased in the levels of bottle gourd pulp there was significant reduction in SNF percentage of Ujanibasundi.

\section{Acidity content}

The acidity content was significantly highest ( 0.46 per cent) in Ujani basundi prepared with addition of 0 per cent bottle gourd pulp $\left(\mathrm{T}_{1}\right)$ while, Acidity content was lowest (0.39) in Ujani basundi prepared with addition of 15 per cent bottle gourd pulp $\left(\mathrm{T}_{4}\right)$, This might be due to the fact that acidity content of bottle gourd pulp was considerably less which utilized for preparation of Ujanibasundi.

More or less similar results were reported by Dubal (2009) reported that acidity of basundi as $0.39,0.46,0.49,0.53$ at $5,10,15$ and in basundi prepared with 20 per cent level of mango pulp, respectively.

Patel and Upadhyay (2003b) also recorded the acidity as $0.47,0.42$ and 0.44 per cent lactic acid for buffalo milk basundi in which sugar was added at three levels viz., 5, 6, and 7 per cent, respectively.

\section{References}

Bhutkar, S. S., S. D. Toraskar and P. B. Shinde, 2015. Standardization And production of traditional Indian Milk Product Basundi from Cow milk with Bottle gourd pulp. IOSR J. of Agriculture and Veterinary Sci., (4): PP19-21.

BIS: 1980. Handbook of food analysis in SP: 18 (part I). Bureau of Indian Standards, ManakBhavan, New Delhi.

Dubal, L. S. 2009. Preparation of basundi blended with mango pulp cv. Alphanso M,Sc. Thesis (unpub.) Submitted to Dr. BSKKV, Dapoli.

Gaikwad, S. M and A. S. Hembade, 2011. Standardization and production of traditional Indian milk product Ujanibasundifrom Buffalo milk Inter J. Live. prod. 2(8):129-133.

Gaikwad, S. M., A. S. Hembade, A. S. Khojare and V. V. Niras, 2009. Cost analysis of traditionally manufactured Ujanibasundi. J. Dairying Food Home Sci., 28:122- 123.

IS: 1224-1977: Determination of fat by Gerber method (Part I). Indian Standard Institute, ManakBhavan, New Delhi.

IS: 1479-1961: Method of test for Dairy Industry (Part II). Chemical analysis of milk. Indian Standards Institute ManakBhavan, New Delhi.

Parle, M and K Satbir, 2011. Is Bottle gourd a natural gourd, Inter Res. J. Of Pharmacy (IJRP) 2(6): 13-17.

Patel, H.G and K.G. Upadhyay, 2003.Stardardization of compositional recipe of cow milk Basundi. Indian $\mathrm{J}$. Dairy Sci., 56(1):15-19.

Raut, M. M. 2018. Studies on preparation buffalo milk basundi with red pumpkin pulp. M.Sc. (Agri.) Thesis (unpub.) Submitted to V.N.M.K.V., Parbhani.

\section{How to cite this article:}

Gawande, S.B., V.G. Atkare and Bhalerao, S.B. 2019. Physico-Chemical Properties of Bottle Gourd Pulp (Lagenaria siceraria) Ujanibasundi. Int.J.Curr.Microbiol.App.Sci. 8(08): 1272-1276. doi: https://doi.org/10.20546/ijcmas.2019.808.149 